\title{
FINANCIAL MANAGEMENT IN STATE AND MUNICIPAL ADMINISTRATION
}

\author{
Alexandra V. Penugalova \\ Kuban State University, Faculty of Economics, Krasnodar, Russia
}

Alexander S. Chulkov

Kuban State University, Faculty of Economics, Krasnodar, Russia

OMESTE

JEL Category: H50, R51, R58

\begin{abstract}
Ongoing modernization of the Russian economy and public finance sector reform involves implementing measures to improve the functioning of the state and municipal organizations providing social services. The purpose of this paper is to develop practical recommendations for improving the delivery mechanism of government (municipal) services in a competitive environment. The article compares in social services, subsidies and analyzed species identified by their distinctive features, identified common characteristics and differences in the mechanism of delivery of services. The main results conducted during the preparation of the article analysis boil down to the fact that for the most efficient delivery of government (municipal) services in a market economy and competitive advantage requires a combination of different types of subsidies and methods of their calculation in conjunction with welldeveloped industry and departmental lists of services.
\end{abstract}

Keywords: public services, efficiency of budget expenditures, budgeting

\section{INTRODUCTION}

The definition of "financial management" is rarely associated with state and municipal sector of the economy. This is since it is difficult to imagine authorities or local governments using some mechanisms that are not clearly regulated by the relevant regulatory act. Especially in the financial sector, where every decision about spending carefully considered by numerous regulatory agencies.

Tools and financial management procedures in the state and municipal government sector have been actively used by governments of economically developed countries since the

Address of the corresponding author:

Alexander S. Chulkov

玤" achulkov@mail.ru second half of the 1980s. By this time, the most common has become a point of view that government agencies and municipalities, as well as private companies, had to use the funds from the maximum return.

For more than twenty years of existence of the practice of financial management in state and municipal institutions of developed countries, an understanding of its essence and core principles have changed significantly. If at the initial stage of the implementation of financial management was considered primarily as instrument control of public expenditure, it is currently understood as a system of management of financial resources of a particular territory, which provides the best ways to use the limited amount of budget resources for effectively and efficiently achieve purposes. 


\section{ON THE WAY TO THE PUBLIC MANAGEMENT}

The starting point of financial management in the public sector and municipal management comparison of costs with the results and determination of relationships between them. As a result of the calculation of the various indicators (economy, effectiveness, efficiency), continuous monitoring of their dynamics and influencing factors are accepted, are satisfied, adjusted and controlled management decisions to increase or decrease budget expenditures for the implementation of certain goals and objectives of the body authorities.

It is important to note the obvious differences between the levels of application of financial management in the private and public sectors. In the first case, it is the level of the enterprise (or group of companies), the public sector - is the level of, industries, sectors of activity of the main managers of budgetary funds or territory.

Another fundamental difference is the goal of financial management. The main objective of financial management at the enterprise maximization of profit and wealth of proprietors of the enterprise in the current and prospective periods by increasing its market value. The main purpose of the financial management in the public sector - to provide more quality services and maximum efficiency of financial resources, which belong to the whole of society. The common of the private and public sectors is that the financial management is part of the control system of an enterprise or a territory.

In most countries where the practice of financial management in public sector, procedures, and financial management standards regulations resolved by the adoption of the relevant laws (USA, Australia), as well as through the creation of special services (agencies) on financial management in the executive branch (Sweden, United Kingdom). Thus, in several foreign governments conducted an internal evaluation of the quality of financial management, which is then used in the practice of management. Often the tools to assess the quality of financial management built into the system of executive power and are the elements of monitoring and control systems.
In developed countries, the financial management in the public administration sector determines, in the following way:

- In the theoretical literature - as "the activities of the state and municipal employees, which includes making decisions and performing other functions that allow you to determine how best to use limited resources efficiently and effectively to achieve political objectives"; - Practical guidelines (for example, the UK) - as "a system of the state financial or municipal agency and control, promoting the objectives of the organization".

In the Russian Federation, normative regulation of financial management in the public sector today is at an early stage of forming. The main efforts on the implementation of financial management quality assessment in practice of the attached now mostly at the federal level, the Ministry of Finance of Russia.

The Ministry of Finance has attempted to define the concept of "financial management" in the sector of public and municipal administration by order of 10 December 2007 № 123n "On the organization of the monitoring of the quality of financial management carried out by the main managers of federal budget", and supplemented it by order of the Ministry of Finance Russia on April 13, 2009 № 34n "On the organization of the monitoring of the quality of financial management, of main administrators of the federal budget".

According to the orders for financial management refers to a set of processes and procedures to ensure effectiveness and efficiency of budget funds and cover all elements of the budget process (drafting of the draft budget, budget execution, accounting and reporting, control and audit) (Gorbacheva, 2015).

Order № 34n part of the quality assessment of indicators of financial management was supplemented by indicators characterizing:

- Proportion of the budget submitted with the planning in the form of a pro-gram (reflecting the introduction of the main administrators of budget funds (MABF) result-oriented budgeting mechanisms;

- The share of allocations, which established the state (municipal), job (MABF shows the ability to determine the cost of providing the 
sovereign governmental or municipal services and to ensure that the results of the cost);

- The quality of the established order of drawing up, approval and management of the budgetgovernmental estimates (characterizes the work of a network within the jurisdiction of the budget planning and execution of the budget);

- Availability of electronic document management system MABF treasury authorities and budgetary funds (illustrates the application of modern technologies of information in the budget process);

- Repayment of the amount of the share of the budget excessively paid or collected sums (as evidence of the implementation of its budget powers main administrators of revenues), etc.

In addition to the above-mentioned legal acts and activities of the Russian Finance Ministry, territorial financial authorities in the development and implementation of financial management items in the budget process are based on the Address of the President to the Federal Assembly. Thus, in the Budget Address for 2015 can distinguish the individual elements of financial management in the public finance sector:

- The effectiveness of budget expenditures and improve the quality of public and municipal services;

- The powers of the budget funds;

- Transparency and efficiency of use of budgetary funds;

- Control over the targeted use of budgetary funds, compliance requirements legislation, and the use of state and municipal property.

In the Address for 2016, the President was talking about improving the quality of financial management in the regions of Russia, on the promotion of the bodies of state power of Russian subjects and local authorities to improve the quality of regional and municipal finance management.

In the Budget Address for 2017, the emphasis is on the fact that the expansion of the powers of chief administrators in the budget should be accompanied by the development of financial management quality monitoring system with the support not only to the target clear direction of their activities but also on the well-established budgetary procedures, internal control mechanisms, a high level of budgetary discipline.

\section{ONGOING REFORM}

From the analysis of the provisions of the budget message, we can make an unambiguous conclusion that the first stages of the implementation of financial management in the practice of state and municipal sectors of primary importance for the bodies of executive authorities have the elements of financial management as budgeting, public expenditure management (with a focus on efficiency and effectiveness), and state and municipal financial control.

The position of local authorities on financial management that is largely due to the actions and decisions of the Russian Ministry of Finance. However, the absence of a single definition of financial management entails the appearance of widely represented municipalities.

The idea is that the new processes in the life of the country, regions, municipalities, require improving the existing public financial management system, including at the local level, directly close to the citizen, which tasks a great variety, the results of their decisions affect the population almost immediately, as financial resources are generally very limited.

Supported by federal and regional authorities in the framework of the current legislation, the present budgetary imbalance between a number of liabilities of local governments and their own income is the confirmation that improves first necessary procedures and municipal finance management mechanisms. To a large extent, the income budgets of many municipal-pal formations formed by financial assistance from higher budgets. This is a real reflection of the fact that the existing level of quality of the financial management at the local level is currently low (Gavrilova, 2015).

In the transition from traditional budgeting to the budget-oriented re-result, radically transformed the public finance management. In the area of budget expenditures there are two important characteristics: the control object becomes a structure of total authority expenditure (in the traditional budget such an object is not used in time funds), and criteria of managerial effectiveness - the achievement of results (in the traditional budget of the agencies success judged by the accuracy of the execution of the budget of painting). 
The starting point of financial management in the public sector and muni-pal management - cost comparison with the results and the definition of their relationships. As a result of the calculation of various indicators (economy, efficiency, effectiveness), continuous monitoring of their dynamics and influencing factors are taken, executed, monitored and adjusted management decisions to increase or decrease budget expenditures for the implementation of certain goals and tasks of agencies. Thus, the effective implementation of the decisions taken duly embodied in the cost structure changes, and these changes, in turn, ensure the achievement of planned results (Loskutova, 2016).

Financial management system, in our opinion, should include two major components - the conditions and processes, which consist of a number of subcomponents. The first component of financial management includes:

1. Laws and regulations:

a. the definition of "financial management in the sector of public and municipal administration" in a special regulatory document adopted by the legislative authorities at federal, regional and municipal governments;

b. the inclusion of provisions on the financial management of all legal acts related to the budget process;

c. the key role of the central authorities (primarily the Ministry of Finance) to create a set of documents aimed at regulating the financial management and covering all four stages of the budget process;

2. The system of distribution of powers and responsibilities within the financial management at the level of regional departments and local governments:

a. the delegation of authority and responsibilities of financial management "top-down" - from the chief executive officer for operational managers (i.e., to the officials of branch and back-office departments, which have at their disposal certain budgets and supervise the implementation of targeted programs, activities, provision government services, and periodically report on the expenditure of funds and achievement of the planned results). This is done in close connection with the establishment of a clear legal responsibility of officials at different levels of the hierarchy of management, for the failure to achieve planned results and the violation of the requirements of normative legal acts. Delegate in conjunction with the responsibility of creating a coherent hierarchical accountability framework that sets out who, when, to whom and for the achievement of any performance report, which is responsible for the improper management (Leyman, 2014);

b. a special role in the financial management system, executed by other subdivisions and departments of authorities - Financial (coordination department budget with the Ministry of Finance, the interaction with the cash budget execution, accounting and management accounting, preparation of financial and management reporting, cooperation with industry and operational units), internal audit and the audit committee, created in the framework of the collective governing body (monitoring and supervision in the field of financial management);

3. Ensuring human and technological capabilities of the financial management:

a. the system of centralized and departmental training of operational managers and internal auditors;

b. the practice of centralized agencies for consultation for financial management;

c. incentive system of civil servants who have attained success in training financial management and its implementation;

d. provision of electronic interaction in real time between information technology systems, operating in the industry and agencies in the organ of cash execution of the budget.

The second component of the system of financial management includes budgetary processes. They are identified by conventional terms, but have a different, compared to the conventional content:

1. Budgeting, characterized by:

a. linking costs with results - in the budget documents, there are results expected 
from the implementation of budget programs and other activities in state and municipal government sector;

b. the presence of the medium-term perspective - the formation of a financial plan as a three-year "rolling" document with the annual plan for the addition of the third year and corrections of plans on the first and second years (especially the former, respectively, second and third);

c. planning unity - linking current or capital expenses and the purchase of assets and services;

d. flexibility in determining the cost structure - decrease in the degree of detailing costs as the level of the management hierarchy, granting authorities the right to carry on next year's allocations are not used to the end of the expiring year;

e. the application of measures to ensure stability in government spending at the macro level - the introduction of fiscal rules and the establishment of a central financial authority limits appropriations for the department as well as, where appropriate, the individual direction costs;

2. Implementation of the budget, through:

a. implementation of a set of agreements or frameworks for the provision of public services (a kind of contracts that provide links between expenditures with results provide authorities considerable freedom of action, and conclude, significantly both between the Ministry of Finance and line ministries, and between the sector ministry or agency, and its subordinate bodies and the Organization);

b. an effective open procedure public procurement (including regular and comparative analysis of the average purchase price);

3. Accounting, covering:

a. the accounting and reporting (including the availability of flexible and streamlined budget classification, publication and presentation of the legislative body of the annual report on the activities of departments and annual financial statements, the accuracy of which is confirmed by the conclusion of the State Audit Institution); b. management accounting and reporting (including the cost of the payment of all budget programs, state and municipal services and other results of authority's activity, as well as the preparation of management reports for operational managers) (Vassel', 2014);

4. Internal control and audit, including:

a. a set of interrelated internal control components (control environment, risk assessment, control activities, information sharing, monitoring) aimed at risk management and the achievement of reasonable assurance in the task implementation of accountability, proper execution of management operations, compliance with legal acts, protection resources from abuse, fraud, and corruption;

b. the presence of special structures: one of them - the internal audit function, which reports directly to the head of the department (and, consequently, does not depend on other departments), audits the financial statements, legality, and efficiency, providing senior executives and operational managers to consulting services.

\section{CONCLUSIONS}

The introduction of modern financial management is closely interlinked in organizations of state and municipal government sector and cardinal increase the efficiency of budget spending. Only their harmonious totality enables an effective budget process in the Russian Federation as a whole and in the Federation and the municipalities of Russia in particular.

It should be noted that the process of integration of financial management mechanism for the public sector to the real budget process carried MABF, is a process that encompasses the need to form hypotheses to be checked in practice, the application of the best financial management practices based on the analysis of international experience, and development of original ideas aimed to solve non-trivial problems. So inevitable errors that require analysis, allowing the result to find the true and only correct direction for further development. This is a complex task facing by all 
the participants of the budget process, and its solution will speak for sure about the practical relevance of the process of financial management for state and municipal government sectors.

\section{WORKS CITED}

Gavrilova, L. A. (2015). Mnogofunktsional'nyye tsentry predostavleniya gosudarstvennykh i munitsipal'nykh uslug: preimushchestva i problemy sozdaniya. Servis Plus, 9(1), 26-33. doi:10.12737/7579

Gorbacheva, O. Y. (2015). Napravleniya optimizatsii seti i chislennosti rabotnikov gosudarstvennykh (munitsipal'nykh) uchrezhdeniy (na primere obrazovatel'nykh uchrezhdeniy). Obrazovaniye $i$ pravo(11-12), 214-221.

Leyman, N. I. (2014). Optimizatsiya ne oznachayet sokrashcheniye. Sovetnik bukhgaltera gosudarstvennogo i munitsipal'nogo uchrezhdeniya(12 (120)), 27-31.

Loskutova, M. V. (2016). The analysis of social and economic efficiency of models and instruments of transformation of the education system. Socio-economic phenomena and processes, 11(1), 6369.

Vassel', T. A. (2014). Byudzhetnyye platezhi za gosudarstvennyye i munitsipal'nyye uslugi. Finance (4), 14-18. Retrieved from http://www.roskazna.ru/upload/iblock/novosti/doc/statya_vasselt._a..pdf

Received for publication: 24.12.2016

Revision received: $\quad 12.01 .2017$

Accepted for publication: 16.01.2017

\section{How to cite this article?}

Style - APA Sixth Edition:

Penugalova, A. V., \& Chulkov, A. S. (2017, July 15). Financial management in state and municipal administration. (Z. Čekerevac, Ed.) MEST Journal, 5(2), 111-116. doi:10.12709/mest.05.05.02.12

Style - Chicago Sixteenth Edition:

Penugalova, Alexandra V, and Alexander S Chulkov. "Financial management in state and municipal administration." Edited by Zoran Čekerevac. MEST Journal (MESTE) 5, no. 2 (July 2017): 111116.

Style - GOST Name Sort:

Penugalova Alexandra $\mathbf{V}$ and Chulkov Alexander $\mathbf{S}$ Financial management in state and municipal administration [Journal] // MEST Journal / ed. Čekerevac Zoran. - Toronto - Belgrade : MESTE, July 15, 2017. - 2 : Vol. 5. - pp. 111-116.

Style - Harvard Anglia:

Penugalova, A. V. \& Chulkov, A. S., 2017. Financial management in state and municipal administration. MEST Journal, 15 July, 5(2), pp. 111-116.

Style - ISO 690 Numerical Reference:

Financial management in state and municipal administration. Penugalova, Alexandra V and Chulkov, Alexander S. [ed.] Zoran Čekerevac. 2, Toronto - Belgrade : MESTE, July 15, 2017, MEST Journal, Vol. 5, pp. 111-116. 